\begin{tabular}{ll}
\hline & $\begin{array}{l}\text { Kastamonu Eğitim Dergisi } \\
\text { Kastamonu Education Journal }\end{array}$ \\
& $\begin{array}{l}\text { Mart 2019 Cilt:27 Sayl:2 } \\
\text { kefdergi.kastamonu.edu.tr }\end{array}$ \\
\hline
\end{tabular}

\title{
Musa Kâzım’ın Osmanlı Eğitim-Öğretimi Üzerine Görüşlerinin Günümüz Eğitim Sistemi Açısından Önemi
}

\section{The Importance in Present-Day Education System of Musâ Kâzım's Opinions About Ottoman Education And Training}

\author{
Seher BÖLÜKBAŞ ${ }^{1}$, Cevdet YAKUPOĞLU ${ }^{2}$
}

\section{Öz}

Musa Kâzım son dönem Osmanlı eğitimcilerinden birisidir. İlk cildini 1894, ikinci cildini 1897 yılında kaleme aldığı Rehber-i Tedris ve Terbiye adlı eseri, öğretmen okullarında okutulmuş ve eğitimcilere yol gösterici olmuştur. Yazar, kitabında öğretmenlerin sahip olması gereken niteliklerden bahsetmiştir. Bu nitelikler günümüzde de geçerliliğini korumaktadır. Musa Kâzım, eserinde öğretim yöntemlerine de değinmiştir. Yazarın bahsettiği bazı yöntemler zaman içerisinde daha da geliş̧iştir. Konuyla ilgili günümüze kadar çok sayıda çalışma yapılmış, bu alanda büyük mesafeler kat edilmiştir. Bu çalışmanın amacı Musa Kâzım'ın içinde yaşadığı dönemdeki eğitim-öğretim anlayışı ile günümüz eğitim sisteminin bir karşılaştırmasını yapmak, yüz yirmi yıllık süreç içinde Türk eğitim sisteminde ne kadar yol kat edildiğini gözler önüne sermektir.

Anahtar Kelimeler: Rehber-i Tedrîs ve Terbiye, Musa Kâzım, eğitim-öğretim, Osmanlı Eğitim Sistemi, II. Abdülhamid Dönemi

\section{Abstract}

Musa Kâzım is the last term Ottoman educators. His work Rehber-i Tedris and Terbiye, which was taught in teacher training schools and was guide to educators, was written up by him as a two skins. Its first skin was written up by him in 1894 and second was written up by him in 1897. In his book, the author mentioned about the characteristicts still protect their validity nowadays. Musa Kâzım also mentioned about teaching methods in the work some methods which mentioned by the author also have been developed in time. Until today lots of works have been made about the subject huge distances have been made. The aim of this study is to compare understanding of education teaching in which period Musa Kâzım lived and todays education system to display how much way have been made in a hundred twenty years.

Keywords: Rehber-i Tedrîs ve Terbiye, Musa Kâzım, Education, Ottoman Education System, II. Abdülhamid Period

1. Kastamonu Ünversitesi, Sosyal Bilimler Enstitüsü Doktora Öğrencisi, Kastamonu, Türkiye; https://orcid.org/0000-0002-5759-3367

2. Kastamonu Üniversitesi, Fen-Edebiyat Fakültesi, Tarih Bölümü, Ortaçağ Tarihi ABD, Kastamonu, Türkiye; https://orcid.org/0000-0002-9637-6314

Atıf / Citation: Bölükbaş, S., \& Yakupoğlu, C. (2019). Musa Kâzım’ın Osmanlı eğitim-öğretimi üzerine görüşlerinin günümüz eğitim sistemi açısından önemi. Kastamonu Education Journal, 27(2), 443-452. doi:10.24106/kefdergi.2501 


\section{Extended Summary}

Musa Kâzım is one of the late Ottoman educators. It is the 121st Sheikh al-Islam of the Ottoman State. In order to guide the teachers and civil servants working in the provinces, he wrote a work called Guidance of education (The first skin of the work was published in 1894 and the second skin was published in 1897.) In this work, Musa Kâzım emphasized the features that should be found in the teacher, the tasks of the teacher and the methods of teaching.

According to Musa Kâzım, the characteristics which must be found in the teacher are that first of all the teacher must be religious. He must respect and obey the Sultan ( The State elders ). He must obey his superiors' orders. (He should not go out of law). He must be respectful to the elders. He must help the poor, the needy. He must be honest. The word he states must be trusted and the promise he gives must be kept. He should be hospitable, able to spend for the ones around him when necessary. She should avoid the cremation. He should wear in clean, and apply a clean-up program for students. He must approach in a good manner against evil. He should not talk unnecessarily. His words should be clear and understandable. You should pay attention to his behaviors and manners in the street, he should be an example for his around. He must be dignified and honorable. First of all, he should not be lazy and but hardworking. He should not neglect his task, he must do what he has to do in a timely manner. He should enter his classes in his time and go out in his time. The person to be a teacher must first be educated in psychology and then study pedagogy.

The teacher's tasks are that they should manage to guide the child's mind to a single area. He should make students read books on morality. He should be able to make activities that will lead students think. The teacher should give importance to lessons such as good writing, painting and so on. He should instill students national and spiritual feelings. Each day, he should try to bring information as an individual, and must add new ones to its current knowledge. He should observe the students well and be able to follow well if they understand the subjects well. He should have the ability to help students separate and consolidate work in activities they will be doing. He should increase their judgment power. He should repeat the lesson. As a matter of fact, students will be able to keep them in memory. He should support the unknown knowledge by known information. Students should give lessons according to their capacities and allocate appropriate break time for each lesson. He should care about the point that there is an order and connection between the courses. Teachers should teach the students according to the law of association. Every individual has different abilities. For this reason, teachers should train in this direction. They should support education with teaching materials and tools. He shouldn't make students into machines, he should provide that they understand the subjects well. The teacher should make a simple and short teaching, and the information given should be a little but useful. Teachers should actively participate in the education system. Although books and the course materials are beneficial for the lesson, they should be able to convey their ideas and thoughts to the students. In each lesson he should refer to the review and synthesis rules. He should also show to his students how to refer. The teacher should take care to make teaching slow and repetitive. Short and clear information is better in the minds of students. Thanks to the repetitions made, the students have a better understanding of the subjects. The teacher should make teaching practical. After the theory part of a lesson is studied, the practice of that lesson must be studied. Teachers should not resort to religious and moral contradictions and methods in teaching. Citizenship education should be given to the students. The aim of the teacher should be to bring well-educated students to the country. The teacher should do the teaching correctly and regularly. He must determine in advance what he will tell. If the teacher's ideas are irregular, the ideas of the students will be irregular. The teacher should try to complete the missing from day to day. Every lesson the teacher makes must be clearer, more useful, and broader than the previous lesson. Teachers should not look old-fashioned, should not change their minds so often. The teacher should personally deal with the student's homework. As a result, he will be able to distinguish between lazy and hardworking. The teacher should make a promise to every student once in every lesson. He should ask questions to each student. He should take the homework at home and after evaluating them he should share the results with that student who has the homework. The teacher should appreciate, likes, encourages and incentive the diligent students. Courses should be designed according to the strength and ability of the students. He should start with the lessons by accepting the level of knowledge of the students at the lowest level, and should emphasize even the easiest thing to them.

Musa Kâzım also mentioned teaching methods in his work. According to this, education must be based on reason. Tools and instruments should be used in education and training. Teaching should be simple and short. Learning should be evaluated. Instruction should be slow and repetitive. Teaching should be practical. Teaching should be based on religion and morality. Teaching is correct and organized. Teaching must be clear and attention-grabbing. Teaching should be based on correcting. Instruction should be in the form of questions and answers. Instruction should be equal to the power of students etc.

All these Musa Kâzım's ideas remain valid today. The place of the teacher in the education system is always important. Teachers should create models for each area in the students. If the teachers are in the leadership of the society, that country will develop in real perspective. The methods specified by Musa Kâzım are still being tried today. It is important that Musa Kâzım thinks these methods in those years. Nowadays some teachers implement these methods, some do not. This is due to the fact that we can not fully systemize education. These rules which Musa Kâzım advocated need to be further developed and applied so that it can save progress in education. 


\section{Giriş}

Yirminci asrın önde gelen Türk-i̇slam âlim ve mütefekkirlerinden olan Musa Kâzım, Osmanlı Devleti'nin 121. şeyhülislamıdır (Yılmaz,2014). Musa Kâzım, öğretmenlere ve taşrada çalışan memurlara rehberlik yapması amacıyla Rehber-i Tedrîs ve Terbiye adlı bir eser kaleme almıştır. ${ }^{3}$ Bu kitap, Selim Sabit Efendi (Buyrukçu,2002)'nin ve Süleyman Paşazade Sami Bey'in (Durukoğlu,2001) kitabından sonra öğretmen okullarında okutulmuş ve yayımlanmış ilk pedagoji kitabı olarak da nitelendirilebilir. İki ciltlik bu eser bir geçiş dönemi kitabı olma özelliği taşır. Bu kitaba ne tam anlamıyla bilimsel ne de tam anlamıyla dinsel demek mümkündür. Yazar zaman zaman batlı kaynaklardan faydalansa da, kitapta daha çok geleneksel eğitimle ilgili açıklamaların ağır bastığı görülmektedir. Yazar, kitapta genel olarak pedagojik yönden eğitim ve öğretime dair kendi fikir ve görüşlerini ortaya koymuştur (Şanal,2011).

Musa Kâzım, çalışmasında öğretim ilkelerini on iki başlık altında toplamıştır:

1. Tedris (Eğitim), akli olmalıdır.

2. Tedris, âlât (âletler) ve edevatla izah ve tefsir edilmelidir.

3. Tedris, basit ve muhtasar olmalıdır.

4. Tedris, tahlilî ve terkibî olmalıdır.

5. Tedris, yavaş ve mükerrer olmalıdır.

6. Tedris, amelî olmalıdır.

7. Tedris, diyanet ve ahlaka müstenit olmalıdır.

8. Tedris, mürettep ve muntazam olmalıdır.

9. Tedris, fasih ve nazar-ı dikkati calib olmalıdır.

10. Tedris, tashihata müstenit olmalıdır.

11. Tedris, sual ve cevap tarzında olmalıdır.

12. Tedris, iktidar-ı şâkirdân ile mütenasip olmalıdır.

Çalışmamızda Musa Kâzım'ın 1890'lı yıllarda kaleme aldığı Rehber-i Tedrîs isimli eserinde bu konular hakkında ortaya koyduğu görüşleri ele alınmış, bu görüşlerin günümüz Türk eğitim-öğretim anlayışı noktasında Türkiye'deki ilmî gelişmelere katkısı üzerine bazı tespitler yapılmış, bu çerçevede Musa Kâzım'ın fikirlerinin Türk Eğitim Tarihi açısından önemi vurgulanmıştır.

\section{Musa Kâzım’a Göre Eğitim-Öğretim Sistemi İçerisinde Öğretmende Bulunması Gere- ken Özellikler, Öğretmenin Görevleri ve Öğretim Yöntemleri}

Musa Kâzım, son dönem Osmanlı eğitim sistemi üzerine yaptığı çalışmalarda psikoloji ve pedagoji ilimlerine büyük önem vermiştir. $\mathrm{O}$, pedagoji ilmiyle psikoloji ilminin birbirini tamamladığını, öğretmen olacak kişinin öncelikle psikoloji ilmine vâkıf olması ve daha sonra ise pedagoji ilmiyle uğraşmaya başlaması gerektiğine vurgu yapmıştı (Musa Kâzım, 1313). Musa Kâzım'dan çok az bir zaman sonra aynı konularla ilgili fikirler üreten yazar Halide Edib de öğretmenlerin eğitim-öğretimde başarı sağlayabilmeleri için psikoloji ilmi hakkında bilgi sahibi olmaları gerektiğinden bahsetmiştir. Halide Edib'e göre bir öğretmenin psikoloji ilmi hakkında fikir sahibi olması öğretmene tatbik edeceği sahayı daha iyi tanımasına firsat sağlayacak, özgüvenini artrracak ve ilmî açıdan gelişiminin olumlu yönde olmasını sağlayacaktır (Güçlü ve Şanal,2005). Bu durum günümüz eğitim anlayışı açısından da önemlidir. Öğrencilerin geçirdiği psikolojik aşamaların bilinmesi (gelişim psikolojisi) ve takip edilmesi, öğrenme süreçlerinin irdelenmesi (öğrenme psikolojisi), öğretim ve eğitimin sağlıklı bir şekilde yürütülebilmesi açısından gereklidir.

Musa Kâzım, öğretmenlerin görevlerinin neler olduğunu sıralarken, öncelikli olarak çocuklardan beklenilen şeylerin yaptırılmasını sağlayıı her türlü etkinliğe başvurmalarını istemiştir. i̇kinci olarak ise çocuğun zihnini tek bir alana yönlendirmeye gayret etmenin öğretmenin en önemli yükümlülüklerinden birisi olduğunun da altını çizmiştir. Musa Kâzım'ın vurgu yaptığı bu nokta bugünkü eğitim sistemimiz açısından da önemlidir. Eğer çocuklar zihinlerini tek bir alana hasrederlerse başarıı olacaklardır. Bu bağlamda çocukların eğitim sürecinin teorik ve pratik uygulamaları esnasında onların dikkatlerini dağıtıcı ve zihinlerini karıştırıcı her türlü eylem ve fiiliyattan uzak tutulmaları bir zorunluluk olarak halen karşımıza çıkmaya devam etmektedir.

Musa Kâzım'ın eserinde dikkat çektiği diğer bire husus da, kötü ahlaklı olduğu tespit edilen öğrencilere özelde verilecek eğitimde göz önünde bulundurulacak işlemlerdir. Yazara göre akranları arasında olumsuz örnek oluşturan bu öğrencilerin tespiti yapılarak bunlara ahlaka dair kitaplar okutulmalıdır. Diğer bir ifade ile Musa Kâzım, günümüzde

3. Eserin ilk cildi 1894 'te, ikinci cildi 1897 yılında yayımlanmıştır. 
de karşılığı bulunan özel eğitim sürecine işaret etmiş, ayrıca yine Türkiye'de bugünkü eğitim sisteminde önemi sıkça tartışılan ahlak eğitiminin gerekliliğine atıfta bulunmuştur. Dolayısıyla Musa Kâzım, eğitim sistemi içerisinde sadece öğretimle yetinilmemesi ve ruhî terbiye ile öğrencilerin özel bir eğitimden geçirilmeleri tezini de günümüzden 120 yıl önce işlemeye çalışmıştır.

Musa Kâzım’a göre, eğitim sürecinde öğrenciyi düşünmeye sevk edici çalışmalara ağırlık verilmeli, ezberin dışına çıkılmalıdır. Musa Kâzım’ın bu düşüncelerine Osmanlı Devleti'nin en önemli eğitimcilerinden biri olan Satı Bey de katılmaktadır. O’na göre; “Anlaşılmadan ezberlenen şeyler hiçbir fayda sağlamaz. Zihinde yabancı olarak kalır. Onun için ne bilgi, ne anlam yerini bulur, ne de düşüncenin yayılmasına yarayabilir, (Oruç ve Kırpık,2006). Bu görüşler, günümüz eğitim sisteminde de öğretmenden istenilen bir yükümlülüktür. Esasen tam bir verim alınamamakla birlikte, ezberci ve kalıpların dışına çıkmayan bir öğrenci profili yıllar önce tüm dünyada geçerliğini yitirmiştir.

Musa Kâzım, öğrencilerin eğitim kalitesinin artırılması noktasında beş duyu organlarına hitap eden ve ruha hoş gelen güzel yazı, resim vb. derslere özen gösterilmesini, çocuklara bu derslerin verilmesinin ihmal edilmemesini istemiştir. Öyle ki resim dersi öğrencilerin hayal yeteneklerini, güzellik ve incelik hissini geliştirir (Oruç ve Kırpık,2006). Bugün de eğer bu derslere özen gösterilirse öğrencilere enerjilerini atmak için firsat yaratılmış olacaktır. Bu da onların diğer derslere daha iyi kanalize olmalarını sağlayacaktır. Yukarıdaki uyarılarının bir devamı olarak Musa Kâzım, eğitimde zevk güzelliğinin öneminden de bahsetmiştir. Ona göre zevk güzelliği, sanat ve estetik ile ruh güzelliğini de beraberinde getirecektir. Yine yazara göre öğrencileri iyi şeyleri sevmeye ve iyi şeyleri yapmaya alıştırmak için onlara daima zevk güzelliğine dair şeyler gösterilmeli, okutulmalı, dinlettirilmeli ve yaptırılmalıdır. Bu anlayış bugünkü eğitim sistemi içinde de özellikle yer almalıdır ki öğrenciler kötü şeylere meyletme oranları asgari düzeyde tutulabilsin. Öyle ki sanat eğitimi, zamanında verilmediği takdirde birey estetik duyarlılık, karşı görüşlere saygı, diğer kültürlere değer verme, eserleri koruma bilincini kazanma ve evrensel ortak değerleri paylaşma davranışlarını kazanamamaktadır (Mercin ve Alakuş,2007). Yukarıda da belirtildiği üzere günümüzdeki eğitim sistemi içinde öğrenciler sanki yarış at gibi muamele görmekte, veliler ve öğretmenler tarafindan en yüksek puanlı okullara yönlendirilmekte, acımasızca sınav sistemi çarkları arasında ezilmelerine göz yumulmaktadır. Okullarda beden eğitimi, resim, müzik, sanat, tiyatro, sinema, gezi, halk oyunları vb. sosyal, kültürel ve sanatsal alanlara yönelen öğrenciler saygın olamama korkusuyla bundan vazgeçmektedirler. Bu alanlara yönelik dersler müfredatta ya yer bulamamakta veya kâğıt üzerinde gösterilip, pratikte bu derslerin saatlerinde öğrencilere matematik, fen ve yabancı dil dersleri gösterilmekte, test çözdürülmektedir. Dolayısıyla öğrencilerin ruhî gelişimlerini olumlu manada etkileyecek olan resim, yazı, beden eğitimi vb. derslere yeterinde ağırlık verilememektedir. Bunlar son derece yanlış uygulamalar olup Musa Kâzım, 100 yıl öncesinde Türk eğitimcilerini bundan kaçınmaları için uyarmıştır. Bu uyarı elbette güncelliğini korumaktadır.

Musa Kâzım’ın eğitim-öğretimle ilgili ele aldığı konular bunlarla sınırlı değildir. O, Türk eğitim sisteminde kendisine yer bulması gerekli olan millî ve manevî konularda, devlet ve toplumla ilgili işlerde, öğrencilerin yakınlarıyla ve akrabalarıyla olan münasebetlerinde üzerlerine düşen görevleri yapmalarının kutsiyetine inanmak gerektiğinin altını çizmiştir (Musa Kâzım, 1313). Bu düşünceler, bugün de öğrencilere telkin edilmek durumundadır. Günümüzün en büyük problemlerinden biri, gençlerin millî ve manevî alanlarda ne gibi sorumluluklarının olduklarını bilmemeleridir. Bu konuda yetersiz olan ve alt yapı yoksunu bir genç, kötü niyetli kişilerin veya örgütlerin ağına kolayca düşebilmekte ve yanlış yerlere sevk edilerek, bir maşa olarak kullanılabilmektedir. Bu durumda gençlerin bu alanlardaki eksikliğinin devlet kurumları tarafindan tamamlanması büyük öneme sahiptir. Aynı zamanda bu konuda tarih öğretmenlerine de önemli roller düşmektedir. Tarih dersi incelendiği zaman, milli-manevi, dinî ahlaki ve sosyal değerlerin oluşturulması ve aktarılmasında alanın değer eğitimine önemli katkılarının olabileceği görülür. Değerlerin geçmişten bugüne nasıl değiştiği, değişme nedenleri, geçmişteki önemli şahsiyetler ve bunların yaşantıları, öğrencilerin değer oluşturmalarında önemli faktörlerdendir. Tarih dersinde öğrenciler, geçmişte toplum için önemli olan değerlerle günümüzde önemli olan değerler arasında karşılaştırmalar yapabilir; tarihteki olay ve kişileri öğrenerek kendileri için dersler çıkarıp değerler oluşturabilirler (Demircioğlu ve Tokdemir,2008).

Musa Kâzım'ın üzerinde hassasiyetle durduğu bir mevzu da, öğrencilerin ve daha geniş manada toplumu meydana getiren bireylerin her gün ayrı ayrı bilgi meydana getirmeye çalışması ve mevcut bilgisinin üzerine mutlaka bir yenisini ilave etmesi gerektiği üzerine olmuştur (Musa Kâzım, 1313). Bu düşünce bugünkü eğitim sistemimiz içinde de kendisine yer bulmaktadır. Eğer bu konuya yeterli önem verilmiyorsa da buna dair gerekli tedbirler alınmalıdır. Çünkü bilgi, geliştirilmez ve kullanılmazsa bilgi olmaktan çıkar ve çöp yığınlarına dönüşür, onu taşıyanı, yük altında bırakarak ezer.

Musa Kâzım, bir ders hocasının sınıfta ders anlatırken öğrencilerin her anlatılana dikkat kesildiğini ve her verilen konunun talebe tarafindan anında anlanıp idrak edildiğini zannetmemesi noktasında uyarılarda bulunmuştur. Ona göre insan çok defalar "gayri ihtiyari dikkat"in esiri olmaktadır. Çağımız eğitim sisteminde de öğretmenler bu hususa dikkat 
etmeli, öğrencilerin dersi dinleyip dinlemediklerini kontrol etmelidirler. Öğretmenler, öğrencilerin okuduklarını tam manasıyla anlamaları için gayret göstermelidirler. Eğer öğrencilerin dikkati derslere güzel bir şekilde yönlendirilebilirse başarının önünde çok fazla engel kalmayacaktır. Bunun için ise öncelikli olarak öğrencilerin dikkatini dağıtacak ortamların temizlenmesi elzemdir. İnternet imkânları, bilgisayarlar, oyunlar, gençlik hareketleri ve ahlak dışı bazı uygulamaların gençlere cazip gelmesi onların dikkatlerini dağıtmaları bir yana, beyinlerini tamamen kontrol altına alabilmektedir. Buna dair her türlü tedbiri almak görev ve sorumluluğu, birinci derecede, Türk Milli Eğitim kurumlarına ve devlete bağlı güvenlik yetkililerine düşmektedir.

Çalışmalarını ele aldığımız son dönem Osmanlı ilim adamı ve eğitimcisi Musa Kâzım, eserinde öğrencilerde "intiza yeteneği”nin geliştirilmesine yönelik ders verilmesi gerektiği üzerine de bazı açıklamalarda bulunmuştur (Musa Kâzım, 1313). "Intiza", bir bütünün parçalarını zihnen ayırıp, ayrıca ve özel bir suretle uzun uzadıya incelemek ve düşünmek yeteneğine denir. Eğer eğitim sisteminde bu yöntem kullanılırsa öğrenciler daha başarılı olacaklardır. Öğrenciler, eğitimle ilgili yapacakları etkinliklerde, işleri kısımlara ayırmalıdırlar. Öyle ki her kısım ayrı ayrı inceleme altına alındığı takdirde, o işte güzel başarı görmemek mümkün değildir. Eğitim sistemimizde bu yöntem sağlıklı ve modern gelişmelere uygun güncellenmiş bir biçimde uygulandığı takdirde çalışmalar daha kolay ilerleyecektir. Ancak yazara göre, "intiza yöntemi"nde pek ileri gidilmemesi gerekmekte; bir konuyu sadece giriş, gelişme, sonuç adlarıyla üç bölüme ayırmak çoğu zaman yeterli olabilmektedir. Bu uyarı bugünkü eğitim sistemimiz açısından da geçerliliğini korumaktadır. Yani öğrenci, fazla ayrıntılarla boğulmamalıdır. Ders çeşitlerinin ve sayılarının artırılması da çözüm değildir. "Bir öğrenci yıl boyunca yirmi ders görürse başarılıdır, on ders görürse daha az bilgi edinir" şeklinde bir yargıya ulaşmak mümkün değildir. Bu nedenle, dersler ve içerdikleri konuların profesyonel bir biçimde sınıflandırılması esas kabul edilmelidir. Diğer yandan konu veya bilgi bütünlüğünün de zarar görmemesi birinci derecede önemlidir.

Yazar, Osmanlı son dönem eğitim sistemi dâhilinde öğrencilerde "tamim yeteneği”nin de geliştirilmesi gerektiğine vurgu yapmıştır (Musa Kâzım, 1313). "Tamim" birleştirme demektir. Günümüzde de öğrencilerin konuları birleştirebilme, "parçadan bütüne gidebilme" yeteneğine sahip olmaları istenen bir durumdur. Haçılı Seferleri'nin Avrupa'ya etkileri konusu ile İslam Dünyası'ndaki etkilerini bir üst başlıkta birleştiremeyen öğrenci, işlediği bu konuları yeterince hazmetmemiş demektir.

Musa Kâzım’a göre, çocukların "muhakeme gücü" artırılmalı ve iki şey arasında muhakeme ederken doğru hüküm çıkarmaya alıştrılmalıdırlar. Bu husus günümüzde de önemlidir. Öyle ki muhakeme edebilen kişiler başka meziyetler de kazanacaklardır. Yaratıı düşünme, doğruyu yanlıştan ayırabilme becerisi gibi... Aksi takdirde öğrenciler her söylenene inanacaklardır. Fransız yazarlarından Descartes'e göre hüküm çıkarmakta basit şeylerde bile acele gösterilmemelidir.

Musa Kâzım, bahsi geçen çalışmasında öğrencilerde "taakkul yeteneği”"nin geliştirilmesine de vurgu yapmıştı. "Taakkul etmek", her şeyin arkasında olan, altında yatan sebepleri aramak demektir. Diğer bir ifade ile öğrenci, derslerinde ve hatta gündelik hayatında aklını kullanmayı becerebilmelidir. Günümüzde de öğrenciler bu yeteneğe sahip olurlarsa ileriki hayatlarında daha başarılı olacaklardır.

Yazarımız, konu akışı içerisinde eğitim kalitesinin yükseltilmesi bağlamında "hafiza yeteneği" bahsini açmıştır (Musa Kâzım, 1313). Ona göre, öğrencilere tarihi olayları hafizalarında korumaları için öncelikle olay aktarılmalı; dersi dinleyen öğrenci var kuvvetini dikkate vermelidir. Yazar, bu çerçevede verilen dersin öğrenciye birkaç defa tekrar ettirilmesi gerektiğini söylemiştir. Günümüz eğitim sisteminde de üzerinde önemle durulan mevzu şudur ki, ders tekrar ettirilirse konular öğrencilerin hafizalarında daha iyi kalacaktır.

Musa Kâzım’a göre, söylenen şey herkesçe malum değilse, bu bilgi başka bir bilgiyle desteklenmelidir. Bilinen bir bilginin verilmesi, aynı muhtevada ancak bilinmeyen bir konunun kavratılmasını sağlayabilir.

Yazar, eğitim üzerine gerçekleştirdiği çalışmasında öğrenci kapasitesi ve teneffüs saatleri hakkında da yorum ve önerilerde bulunmuştur. Ona göre, öğrencilere kapasitelerine göre az ders verilmelidir. Her ders için uygun bir teneffüs zamanı ayrılması da elzem olan bir konudur (Musa Kâzım, 1313). Günümüz eğitim sisteminde de uzmanlar, dinlenemeyen, zihnini toparlayamayan, sabah zinde uyanamayan ve okula gitmekten çekinen bir öğrencinin başarılı olmasının mümkün olmadığını belirtmektedirler. Bugün Türkiye genelindeki bazı okullarda, öğrencilerin uygun olmayan mekânlarda eğitim görmesi ve bundan dolayı da idarecilerin teneffüs saatlerinden çalmak zorunda kalmaları gibi modern eğitim anlayışına uygun olmayan görüntülerle halen karşılaşılmaktadır. Teneffüs saatleri yeterli olmayan bir okulda, hele hele yaşı küçük olan bir öğrenci en temel tuvalet intiyacını bile karşılamaktan aciz kalacaktır. Böyle bir öğrencinin dersi takip etmesi, verim alması ise neredeyse imkânsızdır. Diğer taraftan Musa Kâzım'ın 120 yıl önce eğitimcileri uyarma gereği duyduğu "ev ödevi vermedeki ölçüyü belirleme" noktasında da aradan geçen bunca zamana rağmen makul bir oran tespit edilememiş ve eğitimciler arasında ödev verip vermeme veya bunun miktarı noktasında tartışmalar uzayıp 
gitmiştir.

Musa Kâzım’a göre, eğiti sürecinde öğrencilere verilecek derslerin arasında bir düzen ve bağlant bulunmalıdır (Musa Kâzım, 1313). Günümüzde de bu konu üzerinde eğitimciler hassasiyetle durmaktadırlar. Ders akışı, dönemlik planlarda iyi oluşturulursa, bu bağ kurulabilir.

Yazarın üzerinde durduğu bir diğer öğretim tekniği ise, öğretmenlerin "iştirak-i tasavvurat (çağrışım) kanunu”na göre öğrencilere ders vermeleridir. Öyle ki her fikir, her düşünce, zihnin her çeşit mahsulü, diğer bir düşünceye bağlı bulunmalıdır (Musa Kâzım, 1313). Bu yetenek, özellikle öğrencilerin tarih dersinde başarılı olmalarını sağlayacaktır. Yazara göre, tarihî olaylarda isnatta bulunurken akıl ve hikmete uygun bir dayanak ortaya koymak gereklidir. İştirak-i tasavvurat yeteneği tarihi süreçte batıl inanışlara da yol açmıştı. Yazar buna karşı öğrencilerin uyarılması gerektiğini söylemiştir. Buna ilaveten tarih derslerinde mutlaka gerekçenin açıklanması gerekir. Sadece ezberle yetinilmemeli, sebeplere inilmelidir. Bu şekilde konular unutulmayacaktır. Öğretimde bu şekilde davranıldığı takdirde öğrencilerin akıl ve hâkimesi genişler, kuvvetlenir. Bugün de ilk- orta dereceli okullarda okutulan tarih derslerinin işlenişi esnasında karşılaşılan önemli problemlerden birisi de budur. Yani sebeplere inilmeden, gerekçe gösterilmeden sadece ezberle yetinilmeye dayalı bir ders akışı... Ayrıca bir öğrencinin bir sonraki okula geçişini sağlayacak sınav sistemi içinde yüksek bir puan alarak istediği okula gitmesini hedefleyen bir eğitim anlayışı benimsendiği için, öğrenciler atlar gibi yarıştrılmakta, her gün yüzlerce sorudan oluşan testlerle boğuşturulmakta, bütün dikkatlerini ezber yapmaya ya da soru şıklarına vermektedirler. Dolayısıyla Musa Kâzım'ın 120 yıl önce tartşmaya açtı̆ı̆ bir problem daha halen çözülebilmiş değildir.

Musa Kâzım, her mesleğin kendine mahsus bir "hayal"i olduğunu ve sekiz on çeşit "hayal" sayılabileceğini söylemiştir (Musa Kâzım, 1313). Bunlar; riyaziyat, sanat, şiir, ticaret, siyasiyat, harp ilmi, öğretim ve eğitim, musiki ve ressamlıktır. Buna göre bir mesleğin hayaline sahip olan kişinin başka bir meslekten habersiz olması mümkündür. Öyle ki herkesin her alanda bilgi sahibi olması imkânsızdır. İnsanların bir alanda uzmanlaşması tercih edilen bir durumdur. Kişi de güçlü bir hayal yeteneğinin olması birçok ilimde fayda sağlar. Eğer hayal yeteneği gelişmemişse öğrenci kuru bir kalıptan kurtulamaz ve sadece bilgi taşıyıp bunu işleyemeyen bir hamal durumuna düşer. Günümüzde eğitimciler dokuz tip mizaçtan ve çoklu zeka kuramından bahsetmektedirler (Selçuk ve Yılmaz, 2015; Talu, 1999; Tuğrul ve Duran 2003). Bazı eğitimciler de öğrencilerin çeşitli yeteneklere sahip olduğunu belirtmektedirler (Dilek,2005). Burada amaç, bir öğrencinin hangi yetenek ya da yetenekleri varsa, bunları tespit etmek ve o yeteneklerin daha da belirginleşmesini, öne çıkmasını sağlamaktır. Bir bireyin var olan yetenekleri köreltiliyorsa ya da bu yeteneklerden bir eğitimci haberdar değilse, orada sağlıklı bir eğitim yapılmıyor demektir. Bugün de eğitim bilimcileri bu konular üzerinde çalışmalar yapmakta, her bireyin farklı yeteneklere sahip olduğunu söylemektedirler. Yine eğitimciler, öğrencilere hayal yeteneğinin kazandırılması gereği üzerinde dursalar da, okullarda uygulanan ders müfredatları incelendiğinde halen bu konuda büyük mesafeler alınamadığı gözlemlenmektedir. Yukarıda da belirtildiği üzere sınav sistemleri, öğrencilerdeki hayal yeteneğinin gelişmesindeki engellerden biridir.

Musa Kâzım’a göre her öğretmen, öğretim kurallarını belleyip onlara göre ders vermelidir. Yazar öğretim kurallarının yayılmasıyla Osmanlı eğitim sisteminde büyük bir ilerleme meydana geleceğini öne sürmüştür (Musa Kâzım, 1313). Bugün için de eğitim sisteminde belli kuralların olması önemlidir. Böyle olduğu takdirde bir düzen sağlanacak ve yazarın da belirttiği gibi eğitimde büyük ilerlemeler kaydedilecektir. Ancak burada dikkat edilmesi gereken husus, tespit edilen ve uygulamaya konulan kuralların sık sık değiştirilmemesidir. Eğitim kuralları sıkı bir süzgeçten geçirildikten sonra uzun vadeli kullanılmak üzere hazırlanmalıdır.

Yazarın, kendi dönemi eğitim sisteminde uygulanmasını istediği diğer bir etkinlik ise eğitim öğretimin ders araç ve gereçleri ile desteklenmesidir. Yazara göre âletlerle destekli okutulan bir ders hem kolaylıkla anlaşılır ve hem de unutulmaz. Ders araç gereçleri ile yapılan öğretim neticesinde öğrencilerin dikkat ve gözlem yetenekleri artar ve genişler. Yazar, öğrencinin görmediği ve anlamadığı şeye çalışmayacağını iddia etmektedir (Musa Kâzım, 1313) ki bu her dönemde geçerli bir iddiadır. Günümüz eğitim sisteminde ders araç gereçlerine çok fazla yer verilmesi gereği üzerinde duran uzmanların sayısı çok fazladır. Bu uzmanlara göre eğitim sistemimizde öğretim, aletlerle ve gereçlerle, görsel ve işitsel materyalle açıklanır ve yorumlanırsa öğrenciler konuları daha iyi anlayacaklardır. Çağın teknik gelişmeleri çerçevesinde buna dair pek çok şey yapılabilir. Kurumlar bu alana dönük maddi yatırımlardan kaçınmamalıdırlar.

Musa Kâzım'ın dikkat çekmeye çalıştı̆ı diğer bir eğitim konusu da, "dersi derste anlama" başarısının artrılması üzerinedir. Ona göre, bir öğrenci derste yazdığı bilgiyi ya da konuyu o anda anlamamış ise sonradan onu hiç anlayamamaktadır. Öğrenciler, anladıkları konuları sevmekte, incelemek istemekte, anlamadıklarını ise körü körüne ezberleyerek işin içinden çıkmaya çalışmaktadırlar. Yazar, öğrencinin anlayan olması, makine olmaması gerektiğine vurgu yapmıştır. Yani modern anlamda Musa Kâzım, robot öğrenci istememektedir. Bugünkü eğitim sistemi içinde en çok tartşılan ko- 
nulardan biri de Musa Kâzım'ın yukarıda bahsettiği bu husustur. Günümüz modern eğitimcileri, öğrencilerin konuları körü körüne ezberlemelerinin önüne geçmek için öğretmenlerin etkin görev almalarını istemektedirler. Öğretmenler öğrencilerle yeteri kadar ilgilendikleri takdirde öğrenciler konuları daha iyi anlayacaklar ve derslerini seveceklerdir. Böyle olduğu takdirde öğrencilerin yaratıcılık, eleştirel düşünme becerisi gibi yetenekleri artacaktır. Öğrencinin dersi derste anlaması için ise günümüzde çok çeşitli yöntem ve teknikler geliştirilmiş olsa da elde edilen verim o ölçüde yüksek orana sahip değildir.

Musa Kâzım’a göre "öğretim, basit ve kısa olmalıdır". Öğretimde söylem ve hitaplarda ağır ifadelerden, karmaşık cümlelerden kaçınılmalıdır. Öğretilecek şey önce kısa olarak beyan olunmalı, esas madde anlatıldıktan sonra ayrıntıya geçilmelidir. Öğretimde verilecek bilgi az, fakat faydalı olmalıdır. Bugün de eğitim sistemimizde bu kurallara uyulursa öğrenciler konuları daha iyi anlayacaklar ve dersleri sevecekler, şevkle sarılacaklardır. Ancak Türkiye'deki eğitim sistemi ve ilgili ders müfredatları incelendiğinde tam tersi bir durum ortaya çıkmaktadır. Örneğin ilkokul öğrencilerinin gördüğü matematik konuları ve derslerde onlardan çözülmesi talep edilen matematik veya fen bilgisi soruları neredeyse bir üniversite öğrencisinin gördüğü yüksek düzeye eşittir. Dolayısıyla Musa Kâzım’ın 120 yıl önce dikkat çektiği “öğretim, basit ve kısa olmalıdır" ilkesi günümüzde pek rağbet görmemekte, on yaşındaki bir öğrenciye dönem boyunca neredeyse yirmi farklı ders okutulmaktadır. Her ders içinde ise yüzlerce teferruat konu verilmeye çalışılmaktadır. Bu yaşlarda cıvıl cıvıl olan bir çocuk, yirmi yaşına geldiğinde eğitimin ağır çarkının sivri dişleri arasında kendisini sıkışmış olarak bulmaktadır. Elbette ki istisnai güzel gelişmeler de yaşanmakta ve şahsi gayret gösteren bazı idareci ve eğitimciler, bahis konusu bu sorunları azaltmaya çalışmaktadırlar.

Yazarın bu konu hakkında ifade ettiği diğer bir husus ise "okullarda sınıflarda verilecek ders, öğrencilerin yeteneğine ve gücüne göre olmalıdır". Bunun aksi uygulandığı takdirde öğrenciler derslerden hiçbir şey anlayamayacaklardır. Öğretmen, öğrencilerin bilgi seviyesini en alt düzeyde kabul ederek derslere başlamalı, en kolay bir şeyi bile onlara önemle anlatmalıdır. Günümüzde de bu yöntem benimsendiği takdirde öğrenciler, bir önceki yıl öğrenemedikleri temel bazı bilgileri öğrenmeye veya en azından yeniden hatılayıp pekiştirmeye imkân bulacaklardır.

Yukarıdaki konularla bağlantılı olarak Musa Kâzım, uyarılarına devam etmiştir. Ona göre, derslerde ele alınan konular ne kadar açık olsa da, birinci sınıf öğrencileri tarafından anlaşılamayabilir. Bu nedenle konuların kısımlara ayrılması gerekir. Her kısmın tatbikinin gösterilmesi ve konunun maksadı neyse birleştirilerek yazılması da faydalı olacaktı. Yazara göre, öğretimin başlangıcı "inceleme" ve sonu "sentez"dir. Öğretmen, her derste inceleme ve sentez kurallarına başvurmalı, nasıl başvurduğunu da öğrencilere göstermelidir. Öğrenciler, bu iki yeteneğe (inceleme, sentez) sahip oldukları takdirde ileride çok fazla başarı göstereceklerdir. Günümüz eğitim anlayışında da öğrencilerin bu yeteneklere sahip oldukları takdirde başarısızlığın önündeki birçok engelin ortadan kalkacağına dair söylemler kuvvetle dile getirilmektedir. Dolayısıyla modern çağlarda da iyi ile kötüyü, doğru ile yanlışı ayırt edebilen gençler yetiştirilmesi isteniyorsa öğrencilerde bu iki yeteneğin gelişmesine ortam hazırlanmalıdır. Bu noktada Musa Kâzım'ın, yıllar öncesinden isabetli tespitlerde bulunmuş olduğu görülüyor.

Yukarıda da benzer öğretim yöntemleri arasında yeri geldiğinde zikrettiği üzere yazar "öğretim, yerli yerinde ve düzenli olmalıdır" prensibini dile getirmiştir. Ona göre, okulda okutulan her bir ders kısımlara ayrılmalı, ayrıca bu kısımlar arasında bir münasebet aranmalıdır. Fakat bir dersi düzenlemek, yerli yerinde anlatmak için o dersin çok fazla kısma ayrılması da doğru olmaz. Öğretimin düzenli olması öğrencilerin konuları daha iyi anlamaları açısından önemlidir. Öğretim düzenli olursa ve bir dersin içeriği kısımlara ayrılırsa dersler daha kolay anlaşılır. Dersin pek çok kısma ayrılması ise öğrencilerin kafasını karıştıracaktır. Öğretmen hangi konuyu ne şekilde anlatacağını önceden belirlemelidir. Öğretmenin fikirleri düzensiz olursa öğrencilerin de fikirleri düzensiz olacaktı. Bu durum her dönemde olduğu gibi günümüz eğitim sisteminde de geçerlidir. Öyle ki öğretmenlerin belli bir düzen içinde konuları anlatmaları; günlük, haftalık ve dönemlik planlar hazırlamaları gerekir ki öğrenciler de dersleri iyi bir şekilde anlayabilsinler.

Yazar, öğretmenin eğitim sistemi içinde aktif bir şekilde yer almasını da özellikle istemiştir. Öğretmen kitaptan/ kitaplardan ve diğer ders materyallerinden yararlanmalı, ancak kendi fikirlerini, düşüncelerini de öğrencilere anlatmalıdır (Musa Kâzım, 1313). Bugün de öğretmenlerin nitelikli olması istenmekte, bütün söylemler bu daire çevresinde gelişmekte, onların mesleklerinde daima ilerleme gösterme arzusu içinde olmaları kendilerinden talep edilmektedir. Sonuç olarak öğretmenler ders materyallerini çağın modern eğitim anlayışına göre yenilemeli, sadece bununla da yetinmeyip kendi fikir ve düşüncelerine de tabiri caizse belli aralıklarla format atmalıdırlar.

Musa Kâzım’a göre "bir öğretmen, günden güne eksiklerini tamamlamaya çalışmalıdır". Öğretmenin her yaptı̆̆ı ders, önceki dersinden daha açık, daha faydalı, daha geniş olmalıdır. Öğretmen eski kafalı görünmemeli, sık sık da fikir değiştirmemelidir (Musa Kâzım, 1313). Günümüzde de bir öğretmen bu duruma dikkat etmeli, öncelikle gelişme ta- 
raftarı ve isteklisi olmalı, nihayetinde ise her yıl kendisini geliştirmelidir ki öğrencilere daha fazla yararlı olabilsin. Yine günümüzde bir öğretmenden beklenen, belli bir çizgide ilerlemesidir. Diğer öğretmenlerin yöntemlerine dikkat etmekle beraber kendi de yeni yöntemler çıkarabilmelidir.

Yazara göre "öğretmen, öğrencinin ödevleriyle bizzat ilgilenmelidir." Öğretmenler ödev kontrolünü düzenli yaparlarsa öğrenciler daha düzenli çalışacaklardır. Bu durum da başarıyı getirecektir. Öğretmen, ödev kontrolü sayesinde, çalışkan ile tembeli birbirinden ayırt edebilmelidir. Öğretmen her derste her öğrenciye en az bir kere söz vermelidir. Her öğrenciye sorular sormalıdır. Ama bunu mevcudu çok olan sınıflarda yapmak bir hayli zor olacaktır. Öğretmen, ödevleri eve götürmeli, kontrol ettikten sonra ödev sahibi o öğrenciyle sonucu paylaşmalıdır. Bu da eğitim-öğretime büyük katkı sağlayacaktır (Musa Kâzım, 1313). Günümüzde de öğretmenler, öğrencilere performans ödevleri vermekte ve bu ödevleri kontrol etmektedirler. Buradaki amaç öğrencilerin performanslarını ölçmek ve bu çerçevede onlara notlar vermektir. Ancak kontrol edilmemiş ev ödevlerine rast gele not vermek, o ödevi vermemekten daha kötü sonuçlar doğuracaktır. Kısacası ev ödevi vermek, öğrencileri daha fazla çalışmaya sevk etmekte, yük fazlası ödev vermek ise öğrenciyi eğitimden soğutmaktadır. İyi öğretmen, burada işaret edilen hassas dengeyi iyi kurabilendir.

Musa Kâzım’a göre "öğretmen gayretli öğrencileri takdir etmeli, beğenmeli, teşvik etmeli, isteklendirmelidir" (Musa Kâzım, 1313). Ödüllendirilen öğrenci derslerine daha iyi çalışacaktır. Çalışmanın hacmine ve başarısına göre ödüllendirme yapılmalı, hak etmeyene ödül vermekten kaçınmalıdır. Böyle yapılmazsa öğrenciler arasında kıskançlıklar başlar ve hatta artar. Günümüzde de eğitim bilimcileri ödül yönteminin öğrenciler açısından ne kadar önemli olduğuna vurgu yapmaktadırlar.

Yazara göre öğretmen, "öğrencilerin eksiklerini tamamlarsa, öğrenciler de çalışmayı severler". Bunun için öğretmenin çok fazla gayret etmesi gerekmektedir. Buna rağmen bazı öğrenciler yine de ilerleme kaydetmeyebilir, istekli hale gelemeyebilirler. Bu nedenle okullarda sınıf mevcudunun az olması öğrenci başarısı için önemli bir etkendir.

Musa Kâzım’a göre "öğretimde soru-cevap yöntemi de kullanılmalıdır”. Ancak bu yöntem kullanılırken sorulacak soruların kısa ve faydalı olması, cevaplarda da konu dışına çıkılmaması gerekmektedir. Diğer taraftan öğretmen, tüm derslerin içeriğini sorulara ayırmalı ve bir sonraki derste nasıl sorular soracağını öğrencilere söylemelidir. Osmanlı Devleti eğitimcilerinden Sat Bey’e göre de soru cevap yöntemi öğretimde çok önemlidir. Öyle ki; öğretmen öğrencilerin derse dikkat edip etmediğini ve konuları anlayıp anlamadıklarını ancak bu yöntemle ölçebilir (Oruç ve Kırpık,2006). Bugün de eğitim sistemimiz içinde soru-cevap yöntemi en çok kullanılan usullerden birisidir. Yazarın söylediği gibi soruların kısa, faydalı olması cevaplarda konu dışına çıkılmaması önemlidir. Günümüz öğretmenleri, ders esnasında test çözme yönteminden bir miktar feragat edip, öğrencilerle soru cevap yöntemli ders işlemeye zaman ayırmalıdırlar.

XIX. yüzyıl sonları Osmanlı eğitim sistemi ve öğretim yöntemleri üzerine bu şekilde kıymetli fikirler serdeden Musa Kâzım’a göre aynı zamanda “öğretim yavaş ve tekrarlı olmalı”dır. Kısa ve net bilgiler öğrencilerin akıllarında daha iyi kalır. Yapılan tekrarlar sayesinde de öğrenciler konuları daha iyi kavrarlar. Yine yazara göre "öğretim, pratik olmalıdır". Bir dersin teori kısmı işlendikten sonra o dersin tatbikine çalışımalıdır. Günümüzde özellikle teknik okullarda ve dershanelerde bu kurallara dikkat edilmekle birlikte, çoğu okul ve sınıfta gerekli özenin gösterilmediği tespit olunuyor. Örneğin bir okulda coğrafya ile ilgili bir dersi alan öğrenciler, çoğu zaman dönem boyunca bir defa bile uygulamaya dönük coğrafi geziye çıkarılmamakta, teori ile yetinmek zorunda kalmaktadırlar. Bu teorik bilgiler ise kısa sürede unutulup gitmektedir.

Musa Kâzım’a göre "öğretim, dine ve ahlaka aykırı hükümler ve yöntemler içermemelidir". Her dersin sonunda din ve ahlaka dair birkaç söz söylenmelidir. Fransız milli eğitim bakanlarından Gizo da "bir okulda genel eğitimin havası din ve ahlaka uygun olmalıdı" demiştir. Bu çerçevede öğrencilere vatandaşlık eğitimi de verilmelidir. Burada tarih dersinin önemi ortaya çıkmaktadır. Bu derste vatan, millet, bayrak, devlet, yönetme biçimi, hak ve sorumluluklar gibi unsurların öğretilmesi ile öğrencilerin vatandaşlık bilinci geliştirilir (Demircioğlu ve Tokdemir,2008). Öğretmenin amacı memlekete iyi yetişmiş öğrenciler kazandırmaktır. Günümüz eğitim sistemi içinde görev alan öğretmenlerden beklenen görevlerden biri de bu olarak gösterilmektedir.

\section{Sonuç}

Osmanlı Devleti Tanzimat Dönemi ile birlikte eğitimde modern usuller kullanmaya başlamıştr. Bu dönemden itibaren modern okullar açılmıştır. Bu okullarda okutulmak üzere pedagoji kitapları yazılmıştr. Musa Kâzım'ın Rehber-i Tedris ve Terbiye adlı eseri de bu kitaplardan birisi ve belki de en önemlisidir. O, bu kitabında Osmanlı Devleti'nin son yıllarında ortaöğretimle ilgili okullarda derslerin işlenişi, öğrenci-öğretmen ilişkileri, sınıf düzenleri, öğretim yöntem ve kuralları, öğretmenlerin eğitim durumları, ders araç ve gereçleri, ev ödevleri vb. konuları ele almıştır. Musa Kâzım’ın iki ciltlik $(1894 ; 1897)$ bu eseri, dönemin eğitim anlayışını aydınlatması bakımından önemlidir. 
Musa Kâzım'ın günümüzden 120 yıl kadar önce eserinde verdiği bilgiler günümüz eğitim sistemine ve anlayışına da ışık tutmaktadır. Yazar, çalışmasında öğretmenlerin sahip olması gereken özellikler hakkında bilgi vermiştir. O'na göre öğretmen adayları terbiye ilmine vakıf olmalıdırlar. Onların çocuk terbiyesi, çocuk psikolojisi, gelişim psikolojisi gibi konularda bilgili olmaları şarttır. Mesleklerinde başarılı olabilmek için günde üç dört saat çalışmalıdırlar. Kitap okumaya önem vermelidirler ki öğrencilere model oluşturabilsinler. Onlar eğitim bilimi ve öğretim yöntemleri ile ilgili yayınları takip etmelidirler. Musa Kâzım’a göre kendisini devamlı surette yenileyemeyen öğretmen, öğrencisine fayda yerine zarar verir.

Musa Kâzım, öğretmenlerin görev bilinci çerçevesinde mesleklerini sevmeleri gerektiğini söylemiş, bu işi profesyonelce yapmaları hususunda fikir beyan etmiştir. Öğretmen, öğrencileri tüm yönleri ile tanımaya çalışmalı, öğrencisiyle bütünleşmeli, öğrencisini ezbercilik hastalığından uzak tutmalıdır. Teorik bilgileri destekleyecek uygulamalara ağırık vermelidir. Onlara güzel yazı, resim, musiki alanlarında da dersler vermeli ya da verdirmelidir. Öğrencisini ağır teknik dersler altında ezmemelidir. Musa Kâzım’a göre öğrencilere çok fazla ödev verilmemelidir. Teneffüs saatlerini tam ayarında tutmalıdır. Başarılı öğrencileri ödüllendirmekten kaçınmamalıdır. Dersi ders saatinde anlamalarını hedef almalıdır. Derste konuyu anlayamayan bir öğrencinin evde ders çalışarak bu açı̆̆ını kapatması zor bir şeydir. Öğretmen, öğrencisine verdiği bütün derslerin önemli olduğunu onlara idrak ettirmelidir. Onlara vereceği derslerin çeşidini ve sayısını dengeli bir şekilde belirlemelidir. Öğrencisine bilgiyi peyderpey nakletmeli, bir anda her şeyi öğrenmesini ondan talep etmemelidir. Öğrencinin olaylar arasında bağ kurmasını, hadiselerin arka planında nelerin olabileceğine dair tahmin yürütmesini sağlayacak bir yöntem izlemelidir. Öğretmen eğer, öğrencisinin muhakeme yeteneğini geliştiremiyorsa, öğrenci yerine bir kukla yetiştirmiş olacaktır. Bunun için öğretmen, inceleme ve sentez yeteneği var olan öğrenciler hayal etmeli ve bu uğurda mesai harcamalıdır.

Musa Kâzım’a göre öğretmenler, ahlaki gelişim noktasında öğrencilere model olmalıdırlar. Müellifin öğretmende bulunması gerekliliğine inandığı kişisel özellikler vardır. Bunlar; ilk olarak öğretmen, dindar olmalıdır. Padişaha (devlet büyüklerine) hürmet ve itaat etmelidir. Amirlerinin emirlerine uymalıdır (Kanunlar dışına çıkmamalıdır). Büyüklere karşı saygılı olmalıdır. Fakirlere, muhtaçlara yardımcı olmalıdır. Dürüst olmalıdır. Sözüne güvenilmeli, verdiği sözü tutmalıdır. Misafirperver olmalı, gerekli hallerde çevresi için harcama yapabilmelidir. İsraftan kaçınmalıdır. Temiz giyinmeli, öğrencileri için temizliğe dair program uygulamalıdır. Kötülüğe karşı iyilikle yaklaşmalıdır. Boş yere gereksiz biçimde konuşmamalıdır. Sözleri net ve anlaşılır olmalıdır. Sokakta hal ve hareketlerine dikkat etmeli, çevresine örnek olmalıdır. Ağırbaşı ve haysiyetli olmalıdır. Her şeyden önce tembel değil çalışkan olmalıdır. Görevini ihmal etmemeli, zamanında yapması gerekenleri derhal yerine getirmelidir. Derslerine saatinde girip saatinde çıkmalıdır. Musa Kâzım’a göre bu sıfatlara sahip olmayanların öğretmenlik yapmaları uygun değildir. Çünkü bu durum tabi olarak öğrencileri olumsuz yönde etkilemektedir. Öğretmenlerin başarısızlıkları öğrencilere de yansımakta, onların sönük bir kişiliğe sahip olmalarına neden olmaktadır. Çünkü öğretmen eğitimde temel unsurdur, eğitime yön veren kişidir.

Musa Kâzım, eserinde öğretim yöntemlerine de değinmiştir. Buna göre öğretim akla dayanmalıdır. Eğitim öğretimde âlet ve edevat kullanılmalıdır. Öğretim basit ve kısa olmalıdır. Öğretim tahlili ve terkibi olmalıdır. Öğretim yavaş ve tekrarlı olmalıdır. Öğretim pratik olmalıdır. Öğretim dine ve ahlaka mugayir olmamalıdır. Yani toplum nazarında karşılığı olan dinî, milli değerlere ters düşen bir eğitim vermemelidir. Öğretim, yerli yerinde ve düzenli olmalıdır. Öğretim, açık ve dikkat çekici olmalıdır. Öğretim, düzeltmelere dayanmalıdır. Öğretim, soru ve cevap tarzında olmalıdır. Öğretim, öğrencilerin gücü ile denk olmalıdır vb.

Sonuç olarak $1890^{\prime}$ Iı yıllarda Osmanlı ülkesinde bazı okullarda (lise ve dengi) dersler vererek öğrenciler yetiştiren ve tecrübelerini de hazırladığı Rehber-i Tedrîs adlı eserinde toplayan Musa Kâzım'ın eğitim- öğretimle ilgili fikir ve görüşleri, tavsiyeleri, uyguladığı yöntem ve teknikler bugün için de geçerliliğini korumaktadır. Onun pedagoji, psikoloji, çocuk terbiyesi, çocuk psikolojisi, öğretim yöntemleri, ders araç ve gereçleri, ödüllendirme, ders çeşitleri, sayıları ve saatleri, ev ödevleri, sınıf mevcutları, yaratıcı düşünce ve beceriyi geliştirme teknikleri, ahlaki gelişim, eğitimde sanat, zevk ve estetik güzelliği gibi eğitimle ilgili çok farklı alanlar üzerine geliştirdiği fikirlerin incelenerek güncellenmesi, günümüz Türk eğitim sistemi için elbette büyük faydalar sağlayacaktır. Belirtilen bu yöntemler ve sunulan öneriler bugün düzenli bir şekilde uygulandığı takdirde birçok eğitim sorunu çözülecektir. Esasen Musa Kâzım'ın çalışmasında öne çıkan fikir ve görüşleri, Türk eğitim sistemimizin tarihî alt yapısının bir asırdan fazla bir zaman diliminde ne kadarlık bir mesafe kaydettiğini de çok güzel ifade etmektedir. Türk eğitim anlayışında büyük bir tarihî birikime sahip olan Türk Milli Eğitimi'nin hakikatte bu birikim ve potansiyelden yeterince yararlanmamış olduğu da bir gerçektir. 


\section{Kaynakça}

Bölükbaş, S. (2016). Rehber-i Tedris ve Terbiye Adlı Eserine Göre Musa Kâzım’ın Eğitim ve Öğretim Üzerine Görüşleri (1894-1897). Yayımlanmamış Yüksek Lisans Tezi. Kastamonu Üniversitesi, Kastamonu.

Buyrukçu, R. (2002). Selim Sabit Efendi'nin Rehnümâ-i Muallimîn'ine Pedagojik Bir Yaklaşım Dini Araştırmalar, 12/4, s. 7-30.

Demircioğlu, í. H. , Tokdemir M. A. (2008). Değerlerin Oluşturulma Sürecinde Tarih Eğitimi: Amaç, İşlev ve İçerik. Değerler Eğitimi Dergisi, 15/6, s. 69-70.

Dilek, D. (2005). Sosyal Bilimler Öğretiminde Öğrencilerin Yeteneklerine Dayalı Konu Merkezli (Dursun Dilek) Tekniği. Dokuz Eylül Üniversitesi Buca Eğitim Fakültesi Dergisi, S: 18, s. 153-159.

Durukoğlu, S. (2001). Süleyman Nesip (Süleyman Paşazade Sami Bey) Hayat, Edebi Kişiliği, Şiirleri. Ankara: Kültür Bakanlığı Yayınları.

Güçlü, M., Şanal M. (2005). Yenileşme Dönemi Eğitimcilerinin Öğretmenlik Mesleğine Bakışları. Erciyes Üniversitesi Sosyal Bilimler Enstitüsü Dergisi, S:18/1, s. 151.

Mercin, L. , Alakuş, A. O. (2007). Birey ve Toplum İçin Sanat Eğitiminin Gerekliliği. D.Ü. Ziya Gökalp Eğitim Fakültesi Dergisi, S: 9, s. 17.

Musa Kâzım, (1313). Taşra Maarif Memurlarına Mahsus Rehber-i Tedris ve Terbiye, İkinci Kısım, İstanbul: Kasbar Matbaası.

Oruç, Ş. , Kırpık, G. (2006.) Tedrisat Mecmuası'ndan Makaleler Osmanlı'da Modern Öğretim, Strateji, Yöntem ve Teknikleri. Ankara: Fersa Matbaacilık.

Selçuk, Z. , Yılmaz, E. D. (2015). Rehber Benim “Dokuz Tip Mizaç Modeli’ne Göre Rehberlik Yaklaşımına Giriş” Ankara: Elma Yayınevi.

Şanal, M. (2011). Musa Kâzım Bey’in (1858-1919) Türk Eğitim Tarihindeki Yeri ve Öğretmenlik Mesleğine iliş̧kin Görüşleri. Akademik Bakış Dergisi, S: 26, s.1-13.

Tuğrul, B. , Duran, E. (2003). Her Çocuk Başarılı Olmak İçin Bir Şansa Sahiptir: Zekanın Çok Boyutluluğu Çoklu Zeka Kuramı. Hacettepe Üniversitesi Eğitim Fakültesi Dergisi, S: 24, s.224-233.

Yılmaz, M. (2014). Musa Kâzım Efendi'de Eğitim Öğretim ve Medreselerin Islahı. Erzurumlu Şeyhulislam Musa Kâzım Efendi Sempozyumu (22-24 Kasım 2013 Erzurum) , Erzurum, s. 2-22. 